\title{
Exploring the triangular relationship among information and communication technology, busi- ness innovation and organizational performance
}

\author{
Bernard T. Widjaja ${ }^{a^{*}}$, Iriana Wihardja Sumintapura ${ }^{b}$ and Ahmad Yani ${ }^{b}$
}

${ }^{a}$ Professor, Lecturer of School of Management Labora Jakarta, Indonesia ${ }^{b}$ Lecturer of School of Management Labora Jakarta, Indonesia

\section{CH R O N I C L E A B S T R A C T}

Article history:

Received: June 142019

Received in revised format: July

252019

Accepted: August 4, 2019

Available online:

August 4, 2019

Keywords:

Innovation

Information and communica-

tion technology

Performance

\begin{abstract}
This study is aimed at exploring the relationship among the information and communication technology, business innovation, and organizational performance. Particularly, the study divides the organizational performance into three measures; namely, financial performance, market performance and production performance. In addition to that the mediating role of innovation in the relationship between information and communication technology and organizational performance is examined. The study tries to find out how the technological innovation or innovation in information technology affects the performance of an organization. The results indicate that there was a relationship between information technology and organizational performance. It is also analyzed that through the usage of information technology, the publicly listed companies in Indonesia could improve their performance. However, no association was found between innovation and organizational performance with reference to Indonesia organizations.
\end{abstract}

C 2020 by the authors; licensee Growing Science, Canada

\section{Introduction}

The success of an organization is determinant through its performance in this competitive business era. The performance of the organization is evaluated against the set missions and vision of the company. The concept of organization performance is very crucial. Poor performance of an organization is attributed to the poor structure or policies that need to be resolved in a careful manner. The results in the form of tools used for measuring the objectives and goals of an organization are involved in the organizational performance. Different opinions have been shown by several researches about the performance of an organization (Damanpour et al., 2009). Activities of recurring are involved in organizational performance to set the goals and overview the progress towards them. Changes are made in the organizational processes to achieve the set goals in an efficient way. According to Abu-Jarad et al. (2010) and Chowdhury et al. (2018), the concept of organizational performance is emerged to an issue for great consideration in the discussion of researchers. According to Heffernan and Flood (2000), it is difficult to measure the organizational performance. The ability of an organization to achieve its goals and objectives through optimum allocation of resources is referred as organizational performance (Daft, 2000). The

\footnotetext{
* Corresponding author.

E-mail address: bernardwidjaja8989@yahoo.com (B. T. Widjaja) 
focus of this research is on the Indonesian companies, which are listed publicly. The publicly listed compares are linked with the investors and for this reason they have been studied in this study. For sustaining in the market, the organizations need to perform well even in the investment terms (Sanchez, 2018). The decision of investors to invest in the publicly listed companies is based on the performance of the company. Therefore, the performance aspect is of great importance and consideration. When the company does not perform well, this affects the investments made by the investors (Fatula, 2018). Several organizations are experiencing issues regarding organizational performance. A number of studies have been conducted to evaluate the aspects for improving the organizational performance. A number of organizations are not able to perform well even with the efforts. It has been found by Gulati and Higgins (2003) that organizations on average survive for about 18 years. For instance, Perwaja Steel Sdn. Bhd as a publicly listed company was established in 1982 and it was not able to survive for more than five years (Zhang et al., 2010; Eketu, 2018). The performance of the companies determines their survival. The company could not survive because of its bad performance. When the important factors related to organizational performance are not considered, the company is likely to fail (Olkiewicz, 2018).

The role of information technology is important in determining the organizational performance. It influences the efficiency of organizational working. A number of organizations have still not implemented information technology as a basic tool (Goodwin, 2014). Information technology implementation requires huge cost and training is required for the employees to learn. For this reason, a number of companies have not implemented IT, as they need to make investment. The cost of implementing IT is high and the staff requires training skills to learn its use and adapt accordingly. This will require another cost investment by the organization. Studies have shown that organizations adopting latest tools and equipment of technology are able to survive and become successful. Such organizations increase their knowledge management level. The organizational performance is improved through use of information technology (Melville et al., 2004).

In this research, we study how technological innovation or innovation in information technology affects the performance of an organization. On the previous research studies, the focus of respondents was on the manufacturing organizations (Rasula et al., 2012; Elad et al., 2017). The focus of this study is on the manufacturing companies and the evaluation of organizational performance. Moreover, the study aims at determining the implementation of performance measures in publicly listed companies. The results of the study can be used as an implication for the publicly listed organizations for enhancing their performance.

\section{Literature review}

\subsection{Organizational Performance}

Organizational performance plays an important role for the success of the organizations. This is a continuous process of activities of an organization to achieve its objectives. Organizations keep on progressing for achieving organizational performance. The achievement of an organization against the set of objectives is measured through the organizational performance. However, it is difficult to measure and define the concept. The organizational performance was defined by Georgopoulos and Tannenbaum (1957) during 50s that it is a part of objective and organizational extension. During that time, the performance was determined through organizational structure, its working, and people. In year 60s and 70s, Yuchtman and Seashore (1967) defined the concept of organizational performance and it was an ability to access the resources in environment. The markets became challenging and competitive in $80 \mathrm{~s}$ and $90 \mathrm{~s}$, in which the concept of organizational performance was considered as a success factor in terms of efficiency and effectiveness. It has been stated by Lusthaus and Adrien (1998); and Campbell et al. (1970) that the performance of an organization utilizing unlimited resources was to achieve the desirable objectives. The concept of organizational performance is subjective in nature and therefore difficult to measure in any private or public sector organization. More effort is required to ensure the effective performance of an organization (Brewer \& Selden, 2000; Elshamy \& Ahmed, 2017). It has been stated by Ling et al. (2010) that the performance of an organization is the total achievements made by all its departments 
working towards mutual goal at a given time. The organizational performance has been defined differently in every decade. The concept has become complex over years. The concept is based on the performance of a company through its operational and administrative functions. These functions result in output and performance. This research has conceptualized the organizational performance as it is related to fairness, effectiveness, and efficiency. Several factors influence the performance of an organization including information technology. Through innovation in processes, organizations can improve their performance (Moustaghfir \& Schiuma, 2013). For improving quality and productivity of work, the factors of efficiency and fairness are also included. An efficient manager is required for achieving improved organizational performance (Al-Zu'bi, 2010). The perception of an individual about the fair treatment of organization is another factor that can affect the performance (Fernandes \& Awamleh, 2006; EmenikeKalu \& Obasi, 2016). The organizational profitability will increase based on these factors in an indirect way.

\section{Innovation}

It is difficult to define innovation because of unavailability of data to make results for innovation. There are different definitions of innovation described in literature. In this study, the lack of data to generate the findings for innovation makes the innovation difficult to define. Most of the definitions of innovation are related to the idea of executing a novel behavior or implementing a new idea in an organization (Damanpour et al., 2009; Oerlemans et al., 1998). Innovation is regarded as a new idea to receive certain benefits including profits and higher revenue (Lafley \& Charan, 2008). Innovation is the result of individual's action rather than an accidental happening. New tools and strategies are adopted as knowledge management and practices are involved in innovation (Bates \& Khasawneh, 2005). This also involves adoption of new skills and ideas for the development of innovative products and services along with procedures and processes. The existing activities are replaced with innovative approaches. Innovation is referred as a resource, which is intangible. Moreover, innovation is the outcome of a nonlinear process between the environment and the organization( Esiagu et al., 2016; Hameed et al., 2018). A number of public companies are working with innovation factor to achieve a competitive position on the market. A positive impact is created by the company on its performance. Large size companies have more access to the resources and capital investment for innovation. Sometimes, companies incur huge investment on innovation but still they are not able to compete in terms of innovative output. Resources are not optimally utilized, which lead the organizations suffer (Unger et al., 2011). This affects the performance of the organization. Irrespective of the size of an organization, the innovation is often linked with organizational performance. A positive influence is reflected by innovation on the organizations irrespective of the size of an organization (Kemp et al., 2003). However, the relationship between performance and innovation is not certain (Bowen et al., 2010; Essien et al. 2016). Through innovation, new knowledge is introduced that distinguishes the firm from competitors, which creates an impact on the performance for a specific time (García-Morales et al., 2008). Isolation mechanisms are created by organizations, which adopt innovation as a knowledge creating approach. The organization is allowed to achieve competitive advantage through innovation, which increase profit margin and high organizational performance. Organizations are able to develop ability for making changes as per the need of environment through innovation (De Jong \& Den Hartog, 2008). The quality of product and quantity is increased with innovation. This fact has been used in this research for evaluating the relationship between innovation and performance of an organization.

\subsection{Information Technology}

The concept of information technology was significantly important during the past 30 years. However, the concept has emerged of great significant in this competitive business era. The use of information technology has been increased by the organization for storage of information and data and motivating employees to adopt the technology. The procedures, products, structure, and organizational services are affected by the adoption of information technology by an organization. The organization can manage routine activities in an efficient way along with the achievement of competitive advantage. Opportunities 
are provided by information technology to the organization. The use of information technology can support the organization in identifying its effective use to make future better. The productivity of an organization can be increased by adapting information technology. The performance of an organization improves through effective working. In large companies such as manufacturing companies, organizational performance is positively influenced through information technology (Shaukat \& Wajid, 2008; Eze, 2018). Performance is positively and directly affected through information technology (Kraemer \& Dedrick, 2001). The performance of an organization cannot be improved if the execution of information technology is not accepted by the employees and its use is not optimized. Alternatively, the use of information technology does not influence performance. Moreover, a negative effect on performance has been reported by Brynjolfsson and Hitt (1996). The ability of an organization to develop new knowledge and implement information system is referred as information technology (Rasula et al., 2012). This concept of information technology has been used in this research study. Based on this concept, there are two factors of information technology. The first factor is of knowledge and second is of implementing tools of IT for achieving greater impact on the performance of an organization.

\subsection{The link between Organizational Performance and Innovation}

Organizations obtain positive results and outcomes through innovation, as it is linked with organizational performance (Moustaghfir \& Schiuma, 2013; Feleke, 2018). There exists an important association between innovation ability and performance of the firm. It is not necessary that innovation result in increase of organizational performance. It has been found by innovation, performance, and IT that there is no influence on the performance of an organization. In certain cases, for the success of an organization, innovation is not the only factor. The link between organizational performance and innovation is under discussion. According to Balkin et al. (2000), a negative relationship exists among these variables. Researchers also support that there is no significant relationship between organizational performance and innovation. A study conducted by Wright et al. (2001) found that innovation creates a positive influence on the performance in an environment, which is not supportive. There is an intense competition among the firms in a hostile environment in which opportunities are low. Organizations working hostile environment become more innovation through development of new products and services. Innovation is made to fulfill the customers' needs, which add to the performance of organizations. The relationship between innovation and performance of an organization is complicated and need to be evaluated further.

\subsection{Link between Organizational Performance and Information Technology}

The use of information technology has increased over recent years. The use of such technology in routine activities of business has increased. The performance of organization can be improved through information technology. It has been revealed by the past studies that improvements can be made in organizational performance through the use of information technology (Brynjolfsson \& Hitt, 1996; Devaraj \& Kohli, 2003; Fengyang, 2018). The company needs to incur investment on adoption of information technology for making the better performance. Past studies have shown that information technology creates a significant positive impact on organizational performance. The results are based on the analysis of 631 companies in USA (Zandi \& Haseeb, 2019). It is not necessary that a positive influence is created by information technology on organizational performance. For short term, a negative impact can be created by information technology on organizational performance (Novak \& Stern, 2008). There is need to learn about the new system and its adaptation, which can create difficulty for the employees in using it. Information technology is not required for every type of work in job activities.

\subsection{Conceptual Framework and research hypothesis}

The conceptual framework is based on Resource Based View (RBV) theory. The theory has been used to link information technology, innovation, and performance of the organization. The theory supports in evaluating the resources of companies such as information and innovation to gain competitive advantage. For sustaining competitive advantage, RBV theory is helpful. The competitive advantage it is based on the capabilities of an organization, which are rare, valuable, and inimitable as well as non-substitutable. 
The organizations can use resource-based theory as a key performance driver, which improves the performance by increasing focus on the resources. RBV is hard to copy as it is unique and it can enable the organization in gaining competitive advantage. The source of competitive advantage can be in terms of human resource, financial, intangible, human, physical, or technological. The focus of research related to RBV is on highly aggregated dependent variable that is referred as firm performance (Ray et al., 2004; Feleke, 2018). Organizational performance has been used as dependent variable in this study. Therefore, it is related to the research. RBV theory is linked with the theories of innovation and social capital. In this way, the evaluation of social network becomes a crucial tool of estimation for innovation, competitive strength, and enterprise growth over the last decades (Gulati \& Higgins, 2003). Organization becomes competitive with the help of innovation as it improves its competitiveness. Innovation is not created through external environmental opportunities rather it requires internal analysis for resource endowment and building competencies. The relationship between innovation and organizational performance can be observed through resource-based view. The theory focuses not only on creating opportunities but also on increasing future value with innovation product output. RBV and innovation has a bilateral relationship. Aspects are explored by RBV, which can evaluate the capacity of a firm to innovation as well renew the assets' value through innovative mechanism. A mutual relationship is created and firm gains value (Kostopoulos et al., 2002; Feleke, 2018).

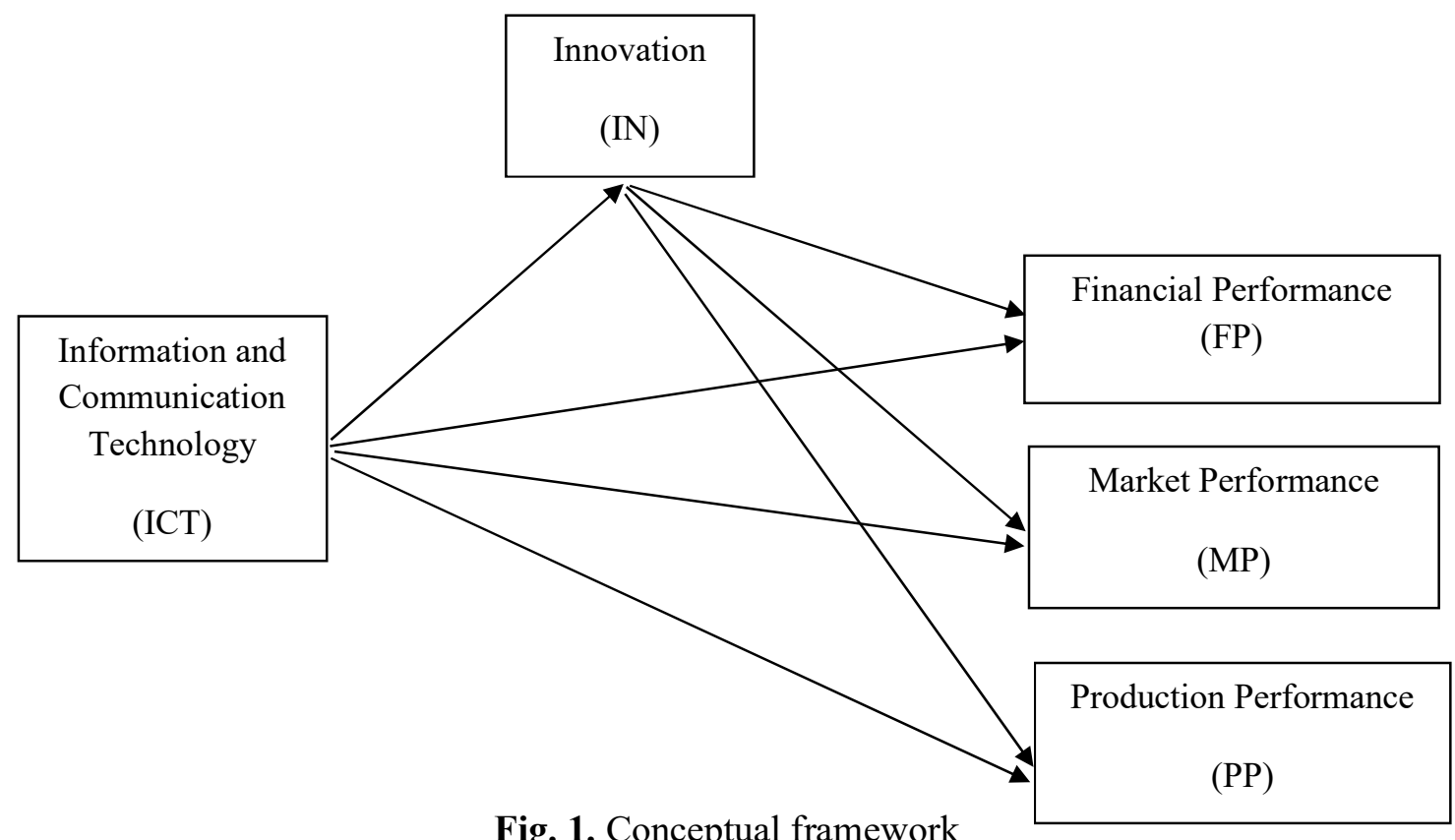

$\mathrm{H}_{1}$ : ICT has significant direct impact on the financial performance.

H2: ICT has significant direct impact on the production performance.

H3: ICT has significant direct impact on the market performance.

H4: ICT has significant direct impact on the innovation.

H5: Innovation has significant direct impact on the financial performance.

H6: Innovation has significant direct impact on the production performance.

H7: Innovation has significant direct impact on the market performance.

H8 Innovation mediates the relationship between ICT and financial performance 
H9 Innovation mediates the relationship between ICT and production performance

H10 Innovation mediates the relationship between ICT and Market performance

\section{Methodology}

A survey-based method is employed for the current study and an adapted questionnaire is used to get the desirable responses. The finance and operational managers from the manufacturing industry are selected as the final respondents or sample for the study. A total of 339 questionnaires was delivered to the targeted managers, which were further distributed to the concerned departments. It took around four weeks to collect the questionnaires back. The questionnaire consisted of four sections and the questions were formulated in English. Section A involves the questions regarding background of the respondent, such as; ethnicity, gender, age, education level, marital status, job category, income, and length of service. Meanwhile, Section B, C, \& D involve questions regarding the elements of the study. The Likert scale 1-5 was used as a measurement scale, where 1 represents strongly disagreed, 2 for disagreed, 3 for neutral, 4 for agreed, and 5 for strongly agreed. The targeted respondents chosen for the study were around 520. Out of 339 distributed questionnaires, only 297 were received back, therefore, the response rate came out to be $69 \%$, which was higher than the threshold level i.e. $45-50 \%$ and were then further used for statistical evaluation. The average age for the targeted respondent was 47. However, 63 percent of the total respondents belonged to the operation department and were being part of that department for more than 15 years. The number of male and female respondents were 233 and 64, respectively, whereas the average working experience came out to be 11 years.

\section{Results}

A structural equation modelling (SEM) was used in this study. SEM is a powerful method, which simultaneously performs the linear regression and the multiple regression, without minor errors. Although, SEM generally involves multiple regression and factor analysis but it can also effectively estimate instrument having multiple regression equations. Among various researchers and academicians, PLS-SEM is a popular approach due to various reasons. Urbach and Ahlemann (2010) analyzed several arguments of scholars and researcher for using PLS technique. Hair Jr et al. (2016) argued that PLS is more suitable particularly when the only purpose is to get detailed explanation and the predictive relevance of the constructs. The present study incorporated this technique for its minimum demand about sample size, flexibility, and effective handling of multiple regressions. Furthermore, the PLS-SEM model distinguishes two constructs, i.e. reflective and formative. The aim of this research is to consider the prediction among constructs. The PLS-SEM consisted of two models; 1) the measurement model, and 2) the structural model. The measurement model under PLS-SEM examines the relation between observed variables and the latent variables. During measurement model estimation, all model items experience some changes. Therefore, it is assumed that strong correlation exists between the variables which integrate to develop a construct. For checking the measurement model's validity, i.e. whether the observed variables are well representing the constructs, a CFA (Confirmatory factor analysis) was performed. The first and second order constructs were calculated under CFA. Furthermore, all elements of the model were examined separately through structural, reflective, and formative modelling. Internal consistency of a model determines the result consistency among the same test items. Binz et al. (2013) suggested that it measures whether similar scores are obtained by the construct measuring items. Therefore, composite reliability (CR) has been examined to assess the reliability or internal consistency of the model. CR does not takes into account constructs' equal indicator loading (Binz et al., 2013). The range of composite reliability is $0-1$, where 0.60 is the threshold level (Henseler et al., 2009), but the most desirable level is 0.7 or above. If the value of CR lies between 0.6-0.7, it represents average internal consistency, whereas an adequate level of internal consistency occurs between 0.7-0.9 (Nunnally \& Bernstein, 1994). Afterwards, the convergent validity for the study was also examined, which is the degree to which same construct measures, which are theoretically associated are actually related to each other (Henseler et al., 2009). Thus, convergent validity reflects the extent of correlation between the same construct measures(Binz et al., 2013). 
While considering the convergent element of measurement construct, average value extracted (AVE) was employed, having 0.50 or above as the threshold value (Henseler et al., 2009). The 0.5 value shows an adequate level of convergent validity. Therefore, according toBinz et al. (2013) half of the indicators' variance is explained by the latent construct and it also determines the adequate convergent validity.

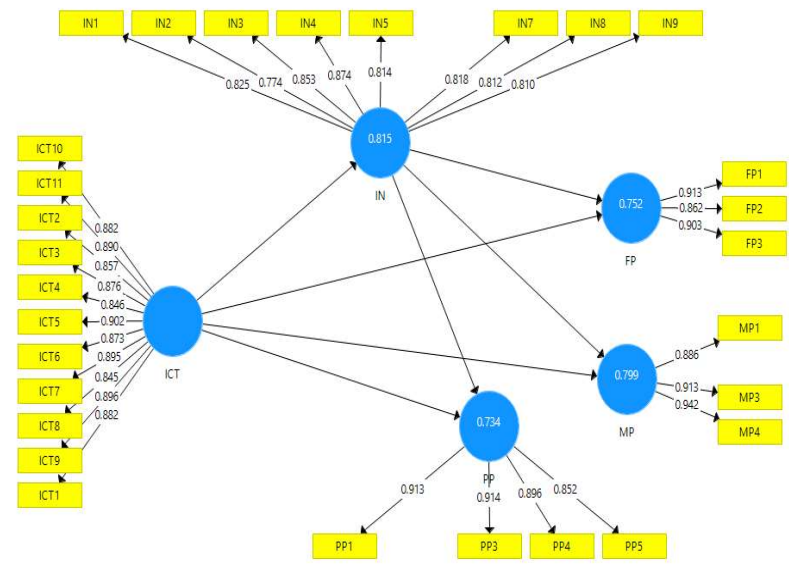

Fig. 2. Measurement Model

Table 1

Reliability

\begin{tabular}{lcccc}
\hline & Cronbach's Alpha & rho_A & Composite Reliability & Average Variance Extracted (AVE) \\
\hline FP & 0.873 & 0.876 & 0.922 & 0.797 \\
ICT & 0.970 & 0.971 & 0.973 & 0.769 \\
IN & 0.932 & 0.933 & 0.944 & 0.677 \\
MP & 0.901 & 0.904 & 0.938 & 0.835 \\
PP & 0.916 & 0.921 & 0.941 & 0.799 \\
\hline
\end{tabular}

The Fornell and Larcker (1981) criterion is a commonly used and powerful measure for determining the discriminant validity in research studies. The relation among reflective variables and the corresponding constructs is measured through discriminant validity. The discriminant validity operationalizes the involved set of variables. Thus, the Fornell and Larcker (1981) criterion has been set as a threshold for the discriminant validity assessment. The reliability index must exhibit its value to be equal to or greater than 0.70 (See Table 1 and Fig 2). The outer and cross loadings were also turned out same. As cross loadings observe the existing correlation between the constructs, thus the discriminant validity among the constructs and variables were examined in this study.

Table 2

Discriminant Validity

\begin{tabular}{lccccc}
\hline & FP & ICT & IN & MP & PP \\
\hline FP & 0.893 & & & & \\
ICT & 0.673 & 0.877 & & & \\
IN & 0.843 & 0.903 & 0.823 & 0.914 & \\
MP & 0.891 & 0.690 & 0.867 & 0.891 & 0.894 \\
PP & 0.847 & 0.698 & 0.844 & \\
\hline
\end{tabular}

At the end, outer loadings were examined for observing the contribution of each indicator in its construct. The value for outer loadings must be equal to or above 0.50 threshold level. Binz et al. (2013) suggested to carefully examine the outer loadings, i.e. if they are above 0.40 but not above 0.70 then it is recommended to be omitted if it causes increase in the values of AVE and CR. After confirmation for the nonexistence of collinearity issue, estimating structural model is the next step. The key measures for estimating PLS-SEM's structural model are coefficient of determination $\left(\mathrm{R}^{2}\right)$, significance of path coefficients, predictive relevance $\left(\mathrm{Q}^{2}\right)$, and the effect size (f2). 
Table 3

Outer Loadings

\begin{tabular}{|c|c|c|c|c|c|}
\hline & FP & ICT & IN & MP & $\mathrm{PP}$ \\
\hline FP1 & 0.913 & & & & \\
\hline FP2 & 0.862 & & & & \\
\hline FP3 & 0.903 & & & & \\
\hline ICT10 & & 0.882 & & & \\
\hline ICT11 & & 0.890 & & & \\
\hline ICT2 & & 0.857 & & & \\
\hline ICT3 & & 0.876 & & & \\
\hline ICT4 & & 0.846 & & & \\
\hline ICT5 & & 0.902 & & & \\
\hline ICT6 & & 0.873 & & & \\
\hline ICT7 & & 0.895 & & & \\
\hline ICT8 & & 0.845 & & & \\
\hline ICT9 & & 0.896 & & & \\
\hline IN1 & & & 0.825 & & \\
\hline IN2 & & & 0.774 & & \\
\hline IN3 & & & 0.853 & & \\
\hline IN4 & & & 0.874 & & \\
\hline IN5 & & & 0.814 & & \\
\hline IN7 & & & 0.818 & & \\
\hline IN8 & & & 0.812 & & \\
\hline IN9 & & & 0.810 & & \\
\hline MP1 & & & & 0.886 & \\
\hline MP3 & & & & 0.913 & \\
\hline MP4 & & & & 0.942 & \\
\hline PP1 & & & & & 0.913 \\
\hline PP3 & & & & & 0.914 \\
\hline PP4 & & & & & 0.896 \\
\hline PP5 & & & & & 0.852 \\
\hline ICT1 & & 0.882 & & & \\
\hline
\end{tabular}

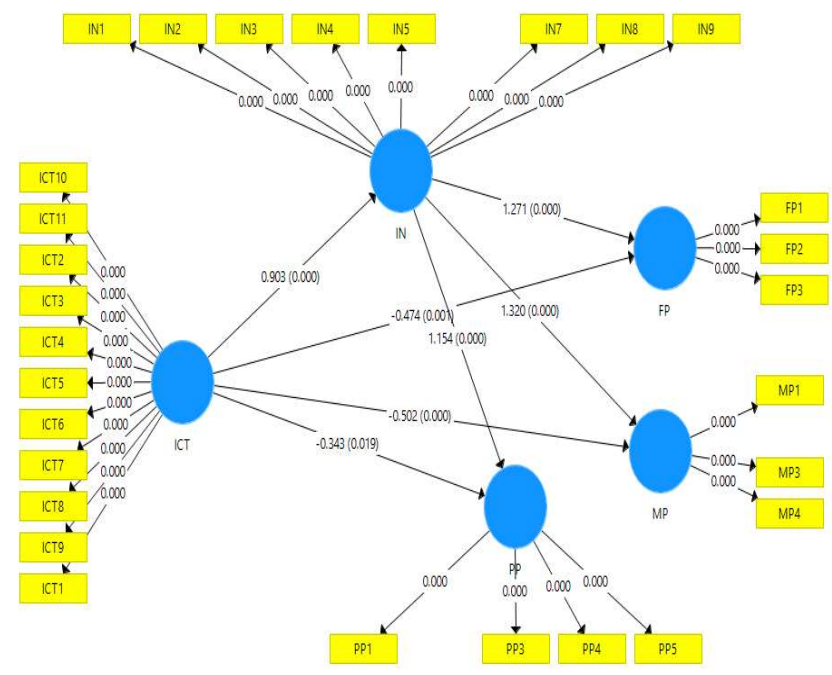

Fig. 3. Structural model

Afterwards, a bootstrapping method was performed which begins with the determination of path model for the direct association among the dependent and independent variables, having no mediators (See Fig. 3 ). The path models involve t-values and path coefficients by using bootstrapping method and algorithm (Binz et al., 2013). The next step involves path model estimation through the mediating variable. The main concern is to observe whether the relationship between mediator and independent variables and between dependent variable and a mediator are significant. Assessing mediating effect is necessary but is insufficient. Lastly, in order to analyze the significant role of the indirect effect, two significant path coefficients' product is divided by the product's standard error. 
Table 4

Direct relationships

\begin{tabular}{lccccc}
\hline & $\begin{array}{c}\text { Original Sam- } \\
\text { ple }(\mathrm{O})\end{array}$ & $\begin{array}{c}\text { Sample } \\
\text { Mean }(\mathrm{M})\end{array}$ & $\begin{array}{c}\text { Standard Deviation } \\
(\text { STDEV })\end{array}$ & $\begin{array}{c}\text { T Statistics } \\
(|\mathrm{O} / \mathrm{STDEV}|)\end{array}$ & $\begin{array}{c}\text { P Val- } \\
\text { ues }\end{array}$ \\
\hline $\mathrm{ICT} \rightarrow$ FP & 0.673 & 0.673 & 0.067 & 10.101 & 0.000 \\
$\mathrm{ICT} \rightarrow$ IN & 0.903 & 0.902 & 0.020 & 44.947 & 0.000 \\
$\mathrm{ICT} \rightarrow$ MP & 0.690 & 0.690 & 0.062 & 11.060 & 0.000 \\
$\mathrm{ICT} \rightarrow$ PP & 0.698 & 0.699 & 0.063 & 10.999 & 0.000 \\
$\mathrm{IN} \rightarrow$ FP & 1.271 & 1.261 & 0.113 & 11.252 & 0.000 \\
$\mathrm{IN} \rightarrow$ MP & 1.320 & 1.312 & 0.100 & 13.194 & 0.000 \\
IN $\rightarrow$ PP & 1.154 & 1.142 & 0.122 & 9.448 & 0.000 \\
\hline
\end{tabular}

A systematic model analysis was accomplished for the structural model, in order to get clear picture of the outcomes for comprehensive testing of the proposed hypotheses. The inner model is evaluated by assessing the direct association among the independent and the dependent variables. PLS-SEM Algorithm was employed to determine the size of path coefficients, whereas, bootstrapping procedure is also employed in SmartPLS 3.0 to check the significance of association. For the number of cases, the original number is used and for the bootstrapping procedure 5000 samples were taken (Binz et al., 2013; Henseler et al., 2009). The direct association among the dependent and independent variables were analyzed in the first model i.e., and a mediating variable is added into the second model to check the relation among this mediator and independent variables, i.e. In addition, the relation among dependent variable and mediator was also analyzed (See Tables 4-6).

Table 5

Direct relationships (Mediation )

\begin{tabular}{|c|c|c|c|c|c|}
\hline & $\begin{array}{c}\text { Original Sample } \\
(\mathrm{O})\end{array}$ & $\begin{array}{c}\text { Sample Mean } \\
\text { (M) }\end{array}$ & $\begin{array}{c}\text { Standard Deviation } \\
\text { (STDEV) }\end{array}$ & $\begin{array}{c}\text { T Statistics } \\
(|\mathrm{O} / \mathrm{STDEV}|)\end{array}$ & P Values \\
\hline $\mathrm{ICT} \rightarrow \mathrm{IN} \rightarrow \mathrm{FP}$ & 1.147 & 1.137 & 0.102 & 11.214 & 0.000 \\
\hline $\mathrm{ICT} \rightarrow \mathrm{IN} \rightarrow \mathrm{MP}$ & 1.192 & 1.183 & 0.092 & 12.889 & 0.000 \\
\hline $\mathrm{ICT} \rightarrow \mathrm{IN} \rightarrow \mathrm{PP}$ & 1.041 & 1.029 & 0.107 & 9.689 & 0.000 \\
\hline
\end{tabular}

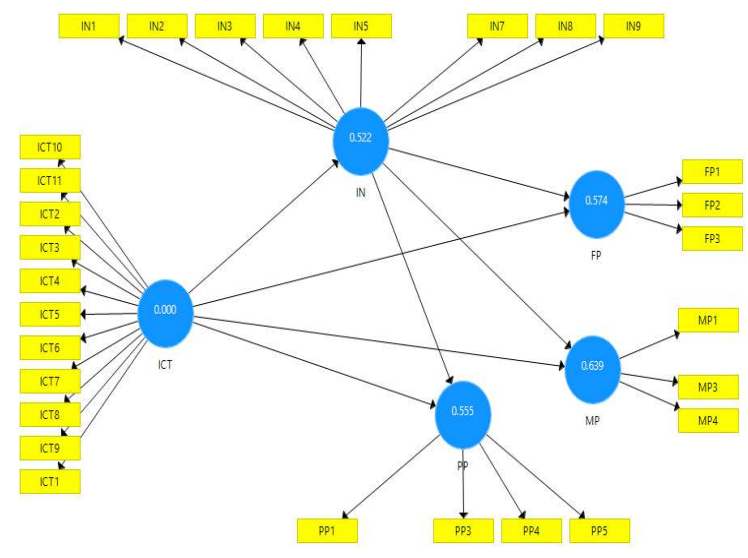

Fig. 4. Predictive relevance

\section{Table 6}

Predictive relevance

\begin{tabular}{lc}
\hline & $\mathrm{Q}^{2}(=1-\mathrm{SSE} / \mathrm{SSO})$ \\
\hline FP & 0.588 \\
IN & 0.516 \\
MP & 0.682 \\
PP & 0.555
\end{tabular}

Predictive relevance of the structural model has also been observed for the study using Stone-Geisser criterion. The criterion observed that whether the inner model predict the endogenous indicators of the 
latent construct(Henseler et al., 2009). Thus, Stone-Geisser's Q2 test was performed through blindfolding procedure to check the predictive relevance of Q2 (Binz et al., 2013; Henseler et al., 2009) and to obtain the measures of cross-validated redundancy for the latent construct.

\section{Conclusion}

This research aimed at exploring the relationship between information technology, innovation, and organizational performance with particular reference to the public sector organizations in Indonesia. The study has achieved all of its objectives. It has been revealed by the results that there was a positive and meaningful relationship between information technology and organizational performance. It has been analyzed that through use of information technology, the publicly listed companies in Indonesia have improved their performance. Alternatively, no association was found between innovation and organizational performance with reference to Indonesia organizations. The study has been successful in addressing the set research objectives. However, future studies can be conducting on analyzing the information technology and innovation for improving the performance of the organization using different aspects. Extensions can be made in relation to this study. A comparative analysis can be done to analyze the way in which organizations improve their performance through innovation, use of knowledge management techniques and information technology. The focus of the study was on the companies, which were listed publicly. Therefore, the future studies can focus on private sector organization and make the comparison of findings of public and private sector companies. To make the study more significant, the research can be conducted using a combination of research method i.e. mixed research method including secondary data and questionnaires. The research model can be extended using variables that are based on practices adopted in public or private or any other type of manufacturing companies. The research study provides practical a theoretical implication based on the findings of the study. The RBV theory partially supports that information technology and innovation results in improving organizational performance. With the focus on public listed companies in Indonesia, the study reveals that a positive impact is created by information technology to improve the performance of the companies and achieve competitive advantage. An important tool for effective working is the use of information technology. Other than this, employees also receive advantage by information technology to avoid lack of knowledge. Further, information technology is also adopted in collaborative works such as conferencing meetings through video.

\section{References}

Abu-Jarad, I. Y., Yusof, N. A., \& Nikbin, D. (2010). A review paper on organizational culture and organizational performance. International Journal of Business and Social Science, 1(3).

Al-Zu'bi, H. A. (2010). A study of relationship between organizational justice and job satisfaction. International Journal of Business and Management, 5(12), 102.

Balkin, D. B., Markman, G. D., \& Gomez-Mejia, L. R. (2000). Is CEO pay in high-technology firms related to innovation? Academy of Management Journal, 43(6), 1118-1129.

Bates, R., \& Khasawneh, S. (2005). Organizational learning culture, learning transfer climate and perceived innovation in Jordanian organizations. International Journal of Training and Development, 9(2), 96-109.

Binz, C., Hair Jr, J. F., Pieper, T. M., \& Baldauf, A. (2013). Exploring the effect of distinct family firm reputation on consumers' preferences. Journal of Family Business Strategy, 4(1), 3-11.

Bowen, F. E., Rostami, M., \& Steel, P. (2010). Timing is everything: A meta-analysis of the relationships between organizational performance and innovation. Journal of Business Research, 63(11), 1179-1185.

Brewer, G. A., \& Selden, S. C. (2000). Why elephants gallop: Assessing and predicting organizational performance in federal agencies. Journal of Public Administration Research and Theory, 10(4), 685-712.

Brynjolfsson, E., \& Hitt, L. (1996). Paradox lost? Firm-level evidence on the returns to information systems spending. Management science, 42(4), 541-558.

Brynjolfsson, E., \& Yang, S. (1999). The intangible costs and benefits of computer investments: Evidence from the financial markets. Paper presented at the Atlanta, Georgia: Proceedings of the International Conference on Information Systems.

Campbell, J. J., Dunnette, M. D., Lawler, E. E., \& Weick, K. E. (1970). Managerial behavior, performance, and effectiveness. 
Chowdhury, T. S., Habibullah, M., \& Nahar, N. (2018). Risk and return analysis of closed-end mutual fund in Bangladesh. Journal of Accounting, Business and Finance Research, 3(2), 83-92.

Daft, R. L. (2000). Organization theory and design. South: Western College Publishing, Thomson Learning. USA.

Damanpour, F., Walker, R. M., \& Avellaneda, C. N. (2009). Combinative effects of innovation types and organizational performance: A longitudinal study of service organizations. Journal of Management Studies, 46(4), 650-675.

De Jong, J. P., \& Den Hartog, D. N. (2008). Innovative work behavior: Measurement and validation. EIM Business and Policy Research, 8(1), 1-27.

Devaraj, S., \& Kohli, R. (2003). Performance impacts of information technology: Is actual usage the missing link? Management Science, 49(3), 273-289.

Eketu, C. A. (2018). Perspectives on Human Nature and Implications for Research in the Behavioural Sciences. International Journal of Emerging Trends in Social Sciences, 4(1), 42-46.

Elad, F., Ngan, W., \& Bongbee, N. (2017). The Role of board characteristics in effective corporate governance: The case of Airbus Group.

Elshamy, H. M., \& Ahmed, K. I. S. (2017). Green fiscal reforms, environment and sustainable development. International Journal of Applied Economics, Finance and Accounting, 1(1), 48-52.

EmenikeKalu, O., \& Obasi, R. (2016). Long-run relationship between marketing of bank services \& the performance of deposit money banks in Nigeria. International Journal of Economics, Business \& Management Studies, 3(1), 12-20.

Esiagu, L. N., Okoroji, L. I., \& Anyanwu, J. O. (2016). Assessment of the role of private enterprises/small businesses on economic growth (A Study of Some Selected SME'S in Imo State, Nigeria). International Journal of Economics, Business and Management Studies, 3(3), 127-135.

Essien, J. M., Gbeghe, B. D., Kpunee, H. N., \& Piabari, N. (2016). E-Marketing products and financial inclusion in Nigeria. International Journal of Economics, Business and Management Studies, 3(1), 47-54.

Eze, P. (2018). An analytical model of demand for hospital inpatient care. International Journal of Social Sciences Perspectives, 2(1), 80-86.

Fatuła, D. (2018). Selected micro-and macroeconomic conditions of wages, income and labor productivity in Poland and other European Union countries. Contemporary Economics, 12(1), 17-32

Feleke, A. T. (2018). Assessment of training and development practice the case of human rights commission hawassa branch. International Journal of Social Sciences Perspectives, 2(1), 38-49.

Feleke, A. T. (2018). Evaluating the quality of coffee product on marketing performance of Ethiopian Commodity Exchange (ECX) Hawassa Branch. International Journal of Social Sciences Perspectives, 2(1), 50-79.

Feleke, A. T. (2018). The dilemma of determining urban administrative Boundary for Land Administration: The Case of Shire Inda Silase. International Journal of Social Sciences Perspectives, 2(2), 126-160.

Fengyang, W. U. (2018). An analysis of Chinas poverty research based on CiteSpace. Journal of Social Economics Research, 5(2), 75-84.

Fernandes, C., \& Awamleh, R. (2006). Impact of organisational justice in an expatriate work environment. Management Research News, 29(11), 701-712.

Fornell, C., \& Larcker, D. F. (1981). Structural equation models with unobservable variables and measurement error: Algebra and statistics: SAGE Publications Sage CA: Los Angeles, CA.

García-Morales, V. J., Lloréns-Montes, F. J., \& Verdú-Jover, A. J. (2008). The effects of transformational leadership on organizational performance through knowledge and innovation. British Journal of Management, 19(4), 299-319.

Georgopoulos, B. S., \& Tannenbaum, A. S. (1957). A study of organizational effectiveness. American Sociological Review, 22(5), 534-540.

Goodwin, B. (2014). No more e-mail? Why companies are turning to collaboration technology. ComputerWeekly.

Gulati, R., \& Higgins, M. C. (2003). Which ties matter when? The contingent effects of interorganizational partnerships on IPO success. Strategic Management Journal, 24(2), 127-144.

Hair Jr, J. F., Hult, G. T. M., Ringle, C., \& Sarstedt, M. (2016). A primer on partial least squares structural equation modeling (PLS-SEM): Sage publications.

Heffernan, M. M., \& Flood, P. C. (2000). An exploration of the relationships between the adoption of managerial competencies, organisational characteristics, human resource sophistication and performance in Irish organisations. Journal of European Industrial Training, 24(2/3/4), 128-136.

Henseler, J., Ringle, C. M., \& Sinkovics, R. R. (2009). The use of partial least squares path modeling in international marketing New Challenges to International Marketing (pp. 277-319): Emerald Group Publishing Limited. 
Kemp, R. G., Folkeringa, M., De Jong, J. P., \& Wubben, E. F. (2003). Innovation and firm performance: EIM Zoetermeer, The Netherlands.

Kostopoulos, K. C., Spanos, Y. E., \& Prastacos, G. P. (2002). The resource-based view of the firm and innovation: identification of critical linkages. Paper presented at the The 2nd European Academy of Management Conference.

Kraemer, K., \& Dedrick, J. (2001). The productivity paradox: is it resolved? Is there a new one? What does it all mean for managers. Center for Research on Information Technology and organizations, University of California Irvine. Retrieved October, 18, 2012.

Lafley, A. G., \& Charan, R. (2008). The game-changer: How you can drive revenue and profit growth with innovation: Crown Business.

Ling, C., Zheng, Y., Yin, F., Yu, J., Huang, J., Hong, Y., . . Pan, D. (2010). The apical transmembrane protein Crumbs functions as a tumor suppressor that regulates Hippo signaling by binding to Expanded. Proceedings of the National Academy of Sciences, 107(23), 10532-10537.

Lusthaus, C., \& Adrien, M.-H. (1998). Organizational assessment: A review of experience. Universalia Occasional Paper, 31.

Melville, N., Kraemer, K., \& Gurbaxani, V. (2004). Information technology and organizational performance: An integrative model of IT business value. MIS Quarterly, 28(2), 283-322.

Moustaghfir, K., \& Schiuma, G. (2013). Knowledge, learning, and innovation: research and perspectives. Journal of Knowledge Management, 17(4), 495-510.

Novak, S., \& Stern, S. (2008). How does outsourcing affect performance dynamics? Evidence from the automobile industry. Management Science, 54(12), 1963-1979.

Nunnally, J. C., \& Bernstein, I. H. (1994). Psychological theory. New York, NY: MacGraw-Hill, 131-147.

Oerlemans, L. A., Meeus, M. T., \& Boekema, F. W. (1998). Do networks matter for innovation? The usefulness of the economic network approach in analysing innovation. Tijdschrift Voor Economische En sociale Geografie, 89(3), 298-309.

Olkiewicz, M. (2018). Quality improvement through foresight methodology as a direction to increase the effectiveness of an organization. Contemporary Economics, 12(1), 69-80.

Rasula, J., Vuksic, V. B., \& Stemberger, M. I. (2012). The impact of knowledge management on organisational performance. Economic and Business Review for Central and South-Eastern Europe, 14(2), 147.

Ray, G., Barney, J. B., \& Muhanna, W. A. (2004). Capabilities, business processes, and competitive advantage: choosing the dependent variable in empirical tests of the resource-based view. Strategic Management Journal, 25(1), 23-37.

Sánchez, V. M. G. (2018). Self-employment, Knowledge and Economic Growth: An empirical study for Latin American countries. Contemporary Economics, 12(4), 473-483.

Shaukat, M., \& Wajid, R. A. (2008). Impact of Information Technology on Organizational Performance: A Comparative Quantitative Analysis of Pakistan's Banking and Manufacturing Sectors.

Unger, J. M., Rauch, A., Frese, M., \& Rosenbusch, N. (2011). Human capital and entrepreneurial success: A metaanalytical review. Journal of Business Venturing, 26(3), 341-358.

Urbach, N., \& Ahlemann, F. (2010). Structural equation modeling in information systems research using partial least squares. Journal of Information Technology Theory and Application, 11(2), 5-40.

Wright, P. M., Dunford, B. B., \& Snell, S. A. (2001). Human resources and the resource based view of the firm. Journal of Management, 27(6), 701-721.

Yuchtman, E., \& Seashore, S. E. (1967). A system resource approach to organizational effectiveness. American Sociological Review, 891-903.

Zhang, J., Yan, C.-H., Chui, C.-K., \& Ong, S.-H. (2010). Fast segmentation of bone in CT images using 3D adaptive thresholding. Computers in Biology and Medicine, 40(2), 231-236.

Zandi, G., \& Haseeb, M. (2019). The importance of green energy consumption and agriculture in reducing environmental degradation: Evidence from sub-Saharan African countries. International Journal of Financial Research, 10(5), 215-227.

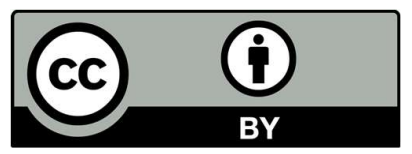

C 2020 by the authors; licensee Growing Science, Canada. This is an open access article distributed under the terms and conditions of the Creative Commons Attribution (CCBY) license (http://creativecommons.org/licenses/by/4.0/). 